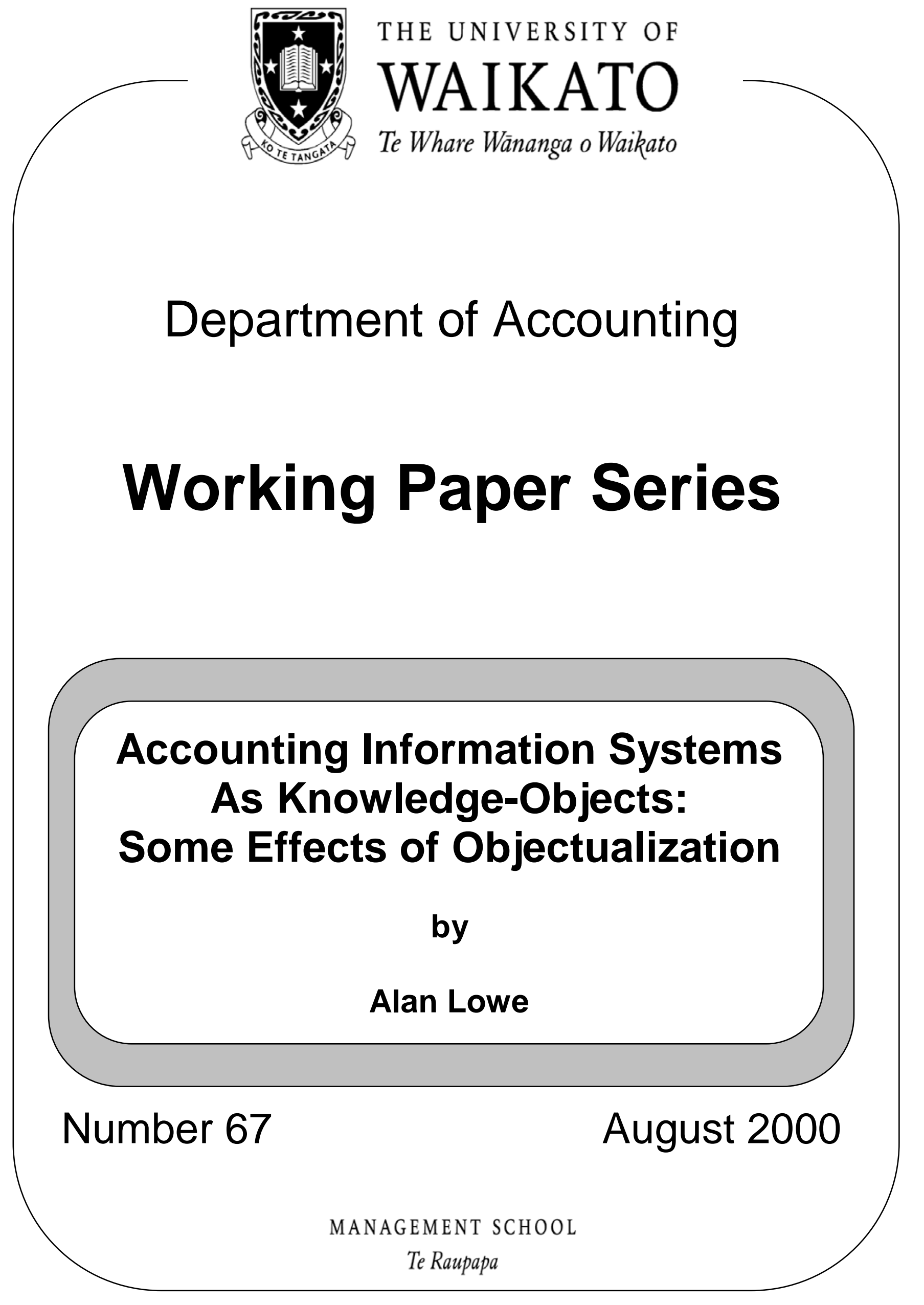


The Working Paper Series is published by the Department of Accounting, University of Waikato, and is intended to provide staff, visitors and postgraduate students with a forum for publishing developing research. The opinions expressed in the various papers in the Series are those of the author(s) and are not necessarily endorsed by the Department. Working Papers are preliminary in nature; their purpose is to stimulate discussion and comment, and any feedback from readers would be welcomed by the author(s).

Correspondence concerning the submission of manuscripts and the receipt of copy may be addressed to:

\author{
The Editor - Working Paper Series \\ Department of Accounting \\ University of Waikato \\ Private Bag 3105 \\ Hamilton, New Zealand \\ Fax: $0064(0) 78384332$
}

Correspondence concerning the reproduction of, or comment on, any part of a Paper should be addressed to the author(s) concerned. 


\title{
ACCOUNTING INFORMATION SYSTEMS AS KNOWLEDGE-OBJECTS: SOME EFFECTS OF OBJECTUALIZATION
}

\section{Alan Lowe}

\author{
University of Waikato \\ Department of Accounting \\ University of Waikato \\ Hamilton, New Zealand \\ Email:alowe1@waikato.ac.nz
}

\begin{abstract}
This paper will outline a research methodology informed by theorists who have contributed to actor network theory (ANT). Research informed from such a perspective recognises the constitutive role of accounting systems in the achievement of broader social goals. Latour, Knorr-Cetina and others argue that the bringing in of non-human actants, through the growth of technology and science, has added immeasurably to the complexity of modern society. The paper "sees" accounting and accounting systems as being constituted by technological "black boxes” and seeks to discuss two questions. One concerns the processes which surround the establishment of "facts”, ie. how "black boxes" are created or accepted (even if temporarily) within society. The second concerns the role of existing "black boxes" within society and organisations. Accounting systems not only promote a particular view of the activities of an organisation or a subunit, but in their very implementation and operation 'mobilise' other organisational members in a particular direction. The implications of such an interpretation are explored in the paper. Firstly through a discussion of some of the theoretic constructs that have been proposed to frame ANT research. Secondly an attempt is made to relate some of these ideas to aspects of the empirics in a qualitative case study. The case site is in the health sector and involves the implementation of a casemix accounting system. Evidence from the case research is used to exemplify aspects of the theoretical constructs.
\end{abstract}

$\begin{array}{lll}\text { Keywords } & * \text { actor network theory } & * \text { knowledge-objects } \\ & * \text { sociology of translation } & * \text { case research } \\ & * \text { casemix accounting }\end{array}$




\section{Introduction}

A strong thesis of 'objectualization' would imply that objects displace human beings as relationship partners and embedding environments or that they increasingly mediate human relationships, making the latter dependent on the former. (KnorrCetina, 1997c, p.1)

This paper is concerned with the implications for management accounting research of accepting a view of accounting systems as knowledge-objects. In taking such a view the paper will outline some developments in Actor Network Theory (ANT). I have drawn most heavily from Knorr-Cetina (see for instance 1997a, 1997b, 1997c) and Latour (1987, 1993). The particular interest of my research is to illuminate our appreciation of accounting systems as technological objects or knowledge-objects. It is for this reason that ANT is used to help conceptualise the empirical case research presented later in the paper. The central concept of ANT is an acceptance of the need for a symmetrical treatment of human and nonhuman actors (Lee and Hassard, 1999). They argue that despite ANT's 'ontological slipperiness' it has much to commend it as a research strategy. More specifically Lee and Hassard (1999) suggest that the insights offered by ANT 'on issues of expertise, boundedness and flexibility... [appear to make it] peculiarly suited to the investigation of key contemporary developments in organizational thinking and practice' (p.393).

As a consequence perhaps the major aim of this paper is to suggest the need to recognise the importance of human relation with objects in the explication of accounting practice. The paper attempts to take seriously the implications of "the expansion of object-centred environments which situate and stabilize selves, define individual identity just as much as communities or families used to do" (Knorr-Cetina, 1997c, p.1). The argument of the paper is that since management accounting is so closely tied to the social effects of technical systems, we ought to be especially concerned to study these objectualised relationships.

This paper argues for a reorientation in our approach to accounting research in organizations. This involves placing more emphasis on the role of the objects of accounting themselves. Accounting systems are actants within networks together with human actors. In researching accounting this means that accounting systems and techniques need to be considered as equals with the human actors in our studies of organisational interaction. The implication is that rather than looking always for a human or super human interest to explain what we find 
in organisations, we need to look for more mundane explanations based upon the intimacy of the bonds between people and technology. Additional explanatory power may be added to our research stories by recognising the constitutive role of accounting systems as black boxes ${ }^{\mathrm{i}}$ or knowledge-objects.

Accounting systems may be perceived as allies, in the pursuit of organisational objectives by human actors. Such a view sees accounting as providing solutions to organisational problems (Miller and O’Leary, 1994). Perhaps more crucially accounting systems, not only promote a particular view of the activities of an organisation or a sub-unit, but in their very implementation and operation 'mobilise' other organisational members in a particular direction. People are 'sucked in' to the accounting system, either in the more conventional manner, because they are constrained to use the numbers the system reports, or more surreptitiously, because their own operational actions and activities are what contributes data to the system.

The past two decades has seen a remarkable growth in the diversity of methodological approaches which have been introduced into the accounting literature. Accounting systems are seen to play a central and crucially constitutive function in the establishment of system/social changes within organisations. There has been increasing research interest in the meaning and roles attributed to accounting and the processual changes occasioned by accounting in organisations. This has led to an increased interest in a wide range of alternative ways of seeing. The accounting literature has reflected this in a burgeoning of papers seeking to introduce and explicate aspects of methodology and social theory. Some writers have argued that the adoption of a diversity of methodological approaches has not always been well articulated (Llewellyn, 1992, 1993; Scapens, 1990). This paper seeks to develop an explanation of the adoption of a specific and distinctive constructionist stream of theorising which has developed in the ANT literature.

The empirical research referred to later in the paper was conducted at a large regional health provider in New Zealand. The subject of that research project was the implementation of a casemix accounting system. The broader context is that of the sweeping health reform policies which have been applied in New Zealand during the early and mid 1990s. 
The next section of the paper seeks to outline the theoretic context of ANT. This section consists of three subsections: firstly a brief discussion of the origins of ANT; secondly a review of the literature on the role of knowledge-objects within society and finally the concept of a symmetrical anthropology is introduced. The third section discusses the relevance of these ideas to management accounting research and reviews the existing accounting literature. Section four provides some reflections on a specific research project. The final section provides brief comments on the application and applicability of the theoretic constructs presented in the paper, and discusses the implications for management accounting research.

\section{ANT, Knowledge-objects and a Symmetrical Anthropology}

This section provides an introduction to a stream of theorising which has developed in the sociology of scientific knowledge (SSK) literature on the role of knowledge-objects within society. Such a conception has been largely responsible for the development of ANT. The section starts with a brief discussion of the origins and nature of ANT. The following subsection engages with the literature which focuses on the constitutive role of knowledgeobjects and technology in contemporary society. Finally the relevance of a 'symmetrical anthropology' to research in organisations is briefly considered.

Locating Actor Network Theory - Classifications of ANT are problematic ${ }^{\mathrm{ii}}$. It is necessary to look toward the sociological literature to make some progress. There it is possible to see discussion of ANT and related literature within SSK. Potter (1996) identifies three streams of theorising within SSK in which Latour is identified with a small group of writers (notably Knorr-Cetina, 1981 and 1996; Latour and Woolgar, 1986; Woolgar, 1992). In this manner it is possible to locate some of the major writers associated with ANT within the related literature of SSK. Potter traces the origins of this theorising to the major stream of phenomenological constructionist theorising attributed to Berger and Luckmann (1966). The other streams of theorising, which constitute the two other identifiable groups, are labelled as "theories of interests ${ }^{\mathrm{iii} "}$ and "empirical relativism ${ }^{\mathrm{iv}}$ (Potter, 1996 p.25).

These three lines of theorising within the sociology of scientific knowledge have their own distinctive features but they share a rejection of the key assumptions of Merton's (1973) 
sociology of science. What they reject is: the view that true knowledge will eventuate given a set of broad social norms; and that the task of the sociologist is to account only for scientific errors.

The constructionist project may be illustrated by the work of Knorr-Cetina (1981, 1982, 1996) and Latour and Woolgar (1986). A distinctive feature of this research is the emphasis on ethnographic studies performed in laboratories and a reduced reliance on interviews and documentation. These constructionist studies involve adopting an anthropological approach. The processes in the laboratory are treated as an exotic culture, observing scientists at the lab bench and examining their approach to data analysis. The analytic studies in this area have concentrated on documenting the role of different constructive activities in fact production (Knorr Cetina, 1995).

Knowledge-objects as Social Objects - This section seeks to develop an analysis of objectcentred sociality (Knorr Cetina, 1996, 1997a, 1997b, Latour, 1993, 1997, Law, 1986, 1996, Cooper, 1992,1995). Traditional social theory and indeed virtually all field research in accounting has adopted a conventional view of human relationships. This emphasis on human relationships may be broadly described as Individualization

\footnotetext{
It implies that single human beings win dividends of modern freedoms at the price of the loss of the benefits which they used previously to accrue from their being embedded in communities of other human beings This understanding of the disembedding of modern selves as exclusively a human relations issue ignores, I shall argue, the ways in which major classes of individuals have tied themselves to object worlds.” (Knorr Cetina, 1997c, p.1).
}

We suggest here that there is a need to recognise the importance of human relation with objects in the explication of accounting practice. This is because it can be argued that "the expansion of object-centered environments which situate and stabilize selves, define individual identity just as much as communities or families used to do” (Ibid, p.1).

If the aim of management accounting research is closely tied to the social affects of technical systems then it follows that we ought to be particularly concerned to study these objectualised relationships. Case study research, in accounting, needs to move beyond the traditional human forms of sociality studied by social scientists and take seriously the affects of technical systems on human identity. The contemporary experience of individualization ignores the degree to which the modern untying of identities has been accompanied by this balancing increase in objectual relations in society. Some writers have theorised this lack of 
human relations as indicating increased alienation (Marx), others have identified terms such as colonisation (Habermas, 1989) to express their concerns over the loss of human sociality and meaning.

Habermas (1989) writes of a loss of "substance”, the life world and cultural traditions. Others (Bourdieu, 1977; Luhmann, 1984) write of the loss of interactional culture. Weber (1905/1930) describes the "diminution of freedom" and the general "disenchantment" of the world. These losses are all seen as caused as a result of "gains": in abstraction; in formal technical systems; in increased legalisation of society and expert and scientific procedures. (see Knorr Cetina, 1994)

It can be argued that viewing contemporary transitions of increasing individualisation and the reduction of the provision of services by the state as simple 'desocialisation' is one-sided. Knorr Cetina argues that:

... the flattened structures, the narrowed principles, the thinned out social relations also coincide with, and to some degree may be propelled by the expansion of other' cultural elements and practices in contemporary life. The retraction of social principles leaves no holes, one imagines, in the fabric of cultural patterns. There has been no loss of texture for society, though what the texture consists of may need rethinking ...relations are not a-social or non-social relations. Rather they are relations specific to late modern societies, which are marked by the interweave of the social as it existed with 'other' cultures. (Ibid, 1997c, p.7).

Knorr Cetina calls these new social fabrications "postsocial relations”. Such social links in 'late modern societies' include those between humans and objects. The growth of technical systems and increase in individualization has been recognised by many writers (Habermas, 1989; Drucker, 1993). Giddens (1990, 1994b) argues that we live in a world of increasingly mediated by expert systems. He suggests that today individuals engage with the wider environment and with themselves through information produced by experts. Such engagements rely on routine interpretations and affect the daily acts of the individual. Giddens offers a view of the rise of expert systems in terms of whole contexts of expert work not just in the growth of scientific-technical elites and the impact of isolated knowledges.

The traditional definition of a knowledge society puts the emphasis on the first term; on knowledge, seen as a specific product. The definition I advocate switches the emphasis to society a society that, if the argument about the expanding role of expert systems etc. is right. is now more inside knowledge processes than outside. In a postsocial knowledge society, mutually exclusive definitions of knowledge processes and social processes are theoretically no longer adequate; we need to trace the ways in which knowledge has become constitutive of social relations (Knorr Cetina, 1997c, p.8, emphasis added). 
In the new sociology of science, it is the centrality of these object worlds to which experts and scientists are oriented that has been emphasised particularly by Callon $(1980,1986)$ and Latour (1987, 1993). These object worlds need to be included in an expanded conception of sociality and of social relations.

Knorr-Cetina places the emphasis on the existence of "instrumental action". The definition of "instrumental action” is derived from Habermas among others. But Knorr-Cetina wishes to draw a distinction between her characterisation of human object relations and those informed by a Habermasian theorisation. Knorr-Cetina perceives a much more enlightened and mutually beneficial relation between human and object. This is not a relation exemplified by alienation (Habermas, 1972) and commodification (eg. Marx, 1968; Slater, 1997) but by 'self-fulfillment, non-alienation and identification'. Such analysis when applied to accounting objects of knowledge can readily be related to a view of accountants as experts. Such people derive identification from their activities and relations with accounting systems and systems of accounting knowledge. Theirs' is not an occupation overcome by alienation and commodification, but is characterised by close relations with objects of knowledge which provide self-fulfillment in their daily practices. This is not to say that there are no oppressive power relation and no commodification of accounting services. There is more to organisational life than alienation and instrumental action. People derive great satisfaction form their interaction with technology and their role as experts. It is the explication of such relations with objects of knowledge that are constituted by systems of accounting and other organisational information system which we might expect to see occupying a greater part of an extended case research agenda.

Aspects of a symmetrical anthropology - A number of SSK writers have been developing research approaches which seek to accommodate these views of the increasingly crucial nature of human object relations. Latour $(1987,1993)$ has been particularly prominent in espousing the significance of styles of research which place the role of knowledge-objects (which he refers to variously as quasi-objects, black boxes and hybrids) and technology seriously. Latour argues that modern thought is predicated on the separation between the objective and subjective worlds. The epistemological dualism of natural objects and the social was, according to Latour, a fine image but one which has brought us increasingly to an impasse. This impasse consists of the inability to understand a world in which we 
increasingly mix objects and society, a world where technoscience has come to be characteristic of our society.

... the networks ... do cross the borders of the great fiefdoms of criticism: they are neither objective or social, nor are they effects of discourse, even though they are real, and collective and discursive...the scientific facts are indeed constructed, but they cannot be reduced to the social dimension because this dimension is populated by objects mobilised to construct it (Latour 1993, p.6, emphasis added).

This is part of a grand strategy required by his and others (Callon, Law, Woolgar) desire to apply a "symmetrical anthropology" to their studies of science in action. Symmetry is not only to be in respect of the attitude taken to the social, "beings among beings" but also in a second way by adopting a similar view of inanimate objects as we do for human subjects. Latour speaks of "collectives" as being composed of associations of social groupings and machines, objects of "technoscience". This is the same conception of social relations which underlies ANT.

Sciences and technologies are remarkable not because they are true or efficient- they gain these properties in addition, and for reasons entirely different from those the epistemologists provide ... but because they multiply the nonhumans enrolled in the manufacturing of collectives and because they make the community that we form with these beings a more intimate one (Latour, 1993, p.108, emphasis added).

Latour uses a very general conception of technology which encompasses anything emerging from what he terms the process of "translation". In this context Latour uses the term to refer to the production or "fabrication", of "quasi-objects". This is most easily seen as consisting of the physical objects which "populate our western societies" and for Latour also includes inscriptions, machines and technology. These hybrids are most easily perceived as technological objects - the result of combining human ideas and physical objects. But they also include much less solid “objects” such as inscriptions, computer software and accounting techniques and rules. I regard accounting and information systems as consisting of mixtures (or perhaps “collectives”) of technological quasi-objects in this very general sense.

One concept which has entered the organization studies/information systems literature, is that of the way in which human actors "delegate"v to technological systems (Bloomfield, 1995; Bloomfield and Verdubakis, 1997a; Bloomfield et al, 1997). This literature examines the way in which the development and impact of information systems within organizations can be related using actor network theory and other constructs such as those discussed in this section. Such interpretations are beginning to be applied to accounting information systems (Munro, 1999) 
Latour and Woolgar (Latour, 1987; Latour and Woolgar, 1986 Woolgar, 1988) conceptualise the "fact producing process" as a "hierarchy of modalisation". For Latour objects including: objects of technology; machines; inscriptions and representational devices; equations and mathematical models, are central to the production and particularly the acceptance of facts (cf Amsterdamska, 1990). Latour's book Science in Action (1987), is effectively structured around a discussion of this hierarchy (see figure 1). The book chapters gradually unravel around this theme. The reader is taken on a convincing journey in which she is confronted with deeper and deeper degrees of explanation, supporting evidence and technology to back up particular claims. This journey toward the "truth" in which "a laboratory [can] raise the world" provides, through an array of historical and contemporary illustrations, what has tended to be regarded as Latour's major treatise. It is largely this concept of fact production, a constructionist view, which underlies the sociology of translation and ANT. The hierarchy of modalisation can be seen to be central to both the nature of the fact construction process and the closely related role of knowledge-objects, and machines and technology within ANT. The hierarchy will be followed closely in section four in order to frame the empirical case material.

Figure 1: A hierarchy of modalisation

The Hierarchy

$\mathrm{X}$ is incorporated

into an instrument

Inscription solidifies facts

$\mathrm{X}$ is a fact

I know that $X$

I claim that $X$

$\mathrm{X}$ is possible
Explanatory Notes

Facts and knowledge are assimilated into inscriptions, machines and technical systems Spokespersons represent/speak on behalf of the "facts" Unsubstantiated claims and anecdote

[adapted from Potter, 1996, p.112]

Toward the bottom of the hierarchy there are descriptions whose status is considered highly suspect or provisional and may be treated as the lies or confusions of the speaker; at the top, there are descriptions which are treated as solid and unproblematic, and quite separate from the speaker. Once a statement comes to be regarded as so unproblematic that they do not even need to be explicitly formulated; they can be presupposed. At this point Latour suggests that 
the statements reach "taken-for-granted" status and begin to be incorporated as inscriptions and within instruments or objects of technology. The processes involved perceive actors engaging with one another and consciously or unconsciously enrolling allies to move their claims in the direction of fact and away from artifact. These allies take the form, in addition to other humans, of texts, inscriptions machines and technology. The more "solid" the physical form the more taken for granted the facts might be regarded. Metaphorically, and in reality, black technological boxes of expertise and technology are enrolled into the fact production process in this manner. This does not typically take place without resistance from other actors.

There are inherent difficulties in presenting stories of the mixing of the social and the technical ("technoscience”), of human actors and technological actants. Many social constructionist and indeed critical theorists have deeply held views of what constitutes the social, "human" agency and indeed the "presentation" of case "stories". Following Latour's construct, researchers must find a way to describe the ways in which these "quasi-objects", which include accounting systems, come to play a part in influencing the behaviour of organisational members. Traditional accounting techniques can be explicated as "black box" technology with which organisations are redefined in economic terms. Together with other devices the use of accounting techniques may be seen as a central part of the process through which change is made acceptable within the organisation. Supporters are enrolled into the change process in part by being exposed to the accounting inscriptions which are used to represent the cost and profit "reality" of their unit and the organisation.

In order to provide an interpretation which is symmetrical (Callon, 1986; Clegg, 1995 ; Law, 1997; Woolgar, 1988) it is necessary to try to represent the role of accounting systems and techniques directly. By direct I mean that the author must seek ways of showing the powerful and constitutive nature of such systems of representation, in ways in addition to the quotes of participants $^{\mathrm{vi}}$. This is consistent with Latour (see also Bloomfield and Best, 1992). It is appropriate to consider how best to provide data to explicate the manner in which technology takes over some of the decisions of human actors or affects the direction of groups in society or organisations. Clearly we cannot rely on what participants say since the whole issue of the impact of technological systems and inscriptions is their pervasive, rather than directly intrusive character (see Bloomfield and Verdubakis, 1997b for a discussion of "framing" 
devices). Latour (1994) argues that it is not possible to "study technical skill directly", that we are still concerned with "meaning but no longer in discourse”(p.39).

This section has argued that we ought to place more weight than is typical on the constitutive role of technology within organisations. That the place of technology and knowledge objects is deeply wound into the networks which constitute out social fabric. Toward the latter part of the section Latour's hierarchy of modalisation is suggested as one way of envisioning the processes which affect our perceptions of what constitutes harder, or softer, facts and indeed what is accepted as technology rather than artifact. The next section reviews the use of ideas from ANT and the sociology of translation in the accounting literature. It will be argued that the use of theoretic constructs from ANT has been very selective and has largely failed to come to terms with the central conception of collectives of human and non-human actors or the need for a symmetrical anthropology.

\section{Accounting Research and the Sociology of Translation}

This section provides a critical review of the contribution of the sociology of translation to the accounting research literature. Latour is credited with developing a number of interesting theoretic constructs which he uses to make sense of the world. Though far from accounting Latour's ideas have made a number of appearances in the accounting literature (Bloomfield et al, 1992; Chua, 1995; Preston et al, 1992; Robson, 1991, 1992, 1994). Though elsewhere the ideas used are often identified as ANT in accounting the more specifically French term of sociology of translation has been adopted. The terms sociology of translation or translation are attributed to Callon (Law, 1997).

Latour offers a complex of theoretical constructs to the intensive case researcher. Many of his ideas have been taken up in the accounting literature. But others have been relatively neglected. The discussions presented earlier have suggested that the role of machines and technology as actors, is central to Latour's theorising. That in explaining the "social" we ought to treat the position of inanimate objects on an equal footing with human actors. Latour does not speak of the need to determine the dualism which is represented by subject and object, human and machine, but of the indeterminacy and intimacy of links between human actors and technological "actants". In the extant literature in accounting and information 
systems the actant element of Latour's ANT is typically either (not mentioned) or avoided (Bloomfield, 1991; Chua, 1995) $)^{\mathrm{vii}}$. Bloomfield states:

While the argument [in this paper] draws heavily on Latour, no attempt is made to evaluate his more ambitious and general thesis concerning 'technoscience' (1991, p.705).

Latour talks of the slow movement of suppositions toward the status of facts. The critical aspect of this "constructionist” view is the way in which facts and ideas become incorporated into inscriptions, machines and technology.

In the accounting literature this "translation" of claims into facts has been illustrated in a number of ways. Ezzamel (1994) reports on the claims and counter claims of two parties to a dispute involving university budgets. Ezzamel describes the controversy as consisting of the more or less successful way in which the protagonists marshal their arguments and "enrol" the accounting data (see also Bloomfield, et al, 1992). The role of accounting inscriptions in this dispute appears to be of some significance. The position of some academics as experts, who are able to act as "spokespersons” is pertinent. These people are able to manage a degree of distance between themselves and the inscriptions. This enables them to emphasise the correctness of their interpretations of the accounting numbers. Others have argued (Bloomfield, et al, 1992; Bloomfield and Best, 1992) that Latour's theories contribute to our ability to "demarcate” the technical and the social (see also Lodh and Gaffikin, 1998).

Chua (1995) relates a story in which accounting numbers are intimately involved in a controversy. Somewhat differently to Ezzamel, Chua describes the way in which one group of protagonists needs to "enrol" the software "Model” in order to succeed in their quest to convince others of their solution to the problem of the efficient provision of health services. Still in Chua's story the role of the technology is relatively marginal. Chua argues that “....it is people who make up accounting numbers in specific ways to try and achieve certain objectives. Software, by contrast, has neither interest nor agency.” (ibid, p.117) ${ }^{\text {viii }}$. Though Chua is correct that "it is people who make up accounting numbers" this is only part of the story since accounting soon escapes the grip of its “designers”. In some sense all accounting numbers might start from human agency but the achievement of "certain objectives" is often superceded by "unintended consequences". It is in seeking to explicate such unintended consequences that a framework based on Latour is likely to be most fruitful. This line of 
theorising would look to explain less as a result of human agency and more as a result of the impact of relatively independent and unfettered accounting systems.

Chua (1995) relates an ethnocentric tale of the way human actors seek allies consisting of accounting inscriptions and accounting systems. In Chua's story the difference between the two is not significant. The administrators must tame the casemix Model in order to obtain the accounting inscriptions they need. In this regard Chua uses the power of the numbers as the key element in the story of fact production (see Robson, 1992, 1994). Robson, being interested in the power of accounting as representation, musters very similar arguments in the rather more removed context of standard setting. Here the production of facts is not just about the inscriptions but also relies on the conventions and culture of accounting as a profession and a professional practice. Robson's emphasis is on the power of the physical representation - the ability to reduce and represent in aggregation what lies beneath the numbers - and the ability this provides to the people who are in positions of power.

An alternative, more strongly ANT, view would place much greater attention on the part played in the establishment of power and influence by knowledge-objects, such as accounting systems. Such an approach does not place human agency in such a central position, but rather sees outcomes as mediated by our tendency to delegate to technological systems. These systems and the representations they produce, which we accept as knowledge, become powerfully constitutive of organisational reality and rationality.

The influence of accounting is closely related to the nature of contemporary culture. We form collectivities of human actors and technological objects in all manner of aspects of contemporary life and work. "Accounting ...is part of the glue that sometimes, and precariously, holds both us and our societies together” (Law, 1991, p.186).

The following section aims to give some explicit illustrations of the way in which accounting systems and accounting inscriptions play such an influential role in our organisations. The section picks up a particular aspect of ANT, namely the hierarchy of modalisation. The empirical material is organised in such a way as to illustrate the way we might see the hierarchy explaining how knowledge-objects, such as accounting systems come to influence people within organisations. 


\section{Reflections on a Research Project}

The following section will present some illustration interpretations from a longitudinal case analysis. The research site was a large regional hospital in New Zealand (see Appendices 1 and 2 for a list of field interactions: interviews and meetings observed). The case research consisted of structured and unstructured interviews. Site visits extended over a period of two years. The interpretations and discussion are intended to emphasise both the technical characteristics and pervasive nature of accounting techniques and such systems as are constructed in relation to medical coding.

This section will illustrate aspects of the hierarchy of modalisation (see figure 1 earlier) as it applied to a particular research project. The evidence will be structured in order to illustrate aspects of the hierarchy and the fact production process as it might be applied to organisational research of management accounting systems. The discussion proceeds by considering different aspects of the modalisation process. In practice these are not discrete but are illustrated separately here for simplicity. Four elements are considered: unsupported rhetorical claims; the role of spokespersons; accounting inscriptions and finally accounting systems as knowledge-objects. Because ANT emphases the importance of technology and knowledge-objects more space will be given to an explanation of this aspect of the research. Consequently the material presented will concentrate on accounting inscriptions and accounting systems as knowledge-objects.

Claims: Organisational Anecdotes - Claims are made as a matter of course in all organisations and are part of everyday social interaction. Most such claims carry little weight and those they are directed at are able to accept or reject them without great influence. Early visits to the hospital provided examples of comments which might be seen as simple claims:

The hospital's accounting was non-existent three years ago. An organisation of over four thousand and only one accountant - it was just ridiculous. Since I arrived I've instituted change right through Finance and the operating Divisions. People now take the accounting numbers seriously. They can't ignore accounting figures and budgets any more. (Interview with Director of Finance, 7th April, 1995)

On taking up the position there was a complete lack of management info. Though some statistical data were collected, this was primarily at the request of the Ministry of Health. A complete absence of cost information. There was a task supervision environment, no attention to the major factors which drove costs. The aim was to come in within budget, no emphasis on efficiency. (Interview with Surgery Division General Manager, July 1994) 
Such comments were often encountered from managers at the hospital indicating a degree of conformity of view. But the substance of these remarks was of little interest to operational staff. To begin to make an impact on clinical, nursing and technical staff more compelling arguments and evidence needed to be deployed.

Latour (1987) suggests that a number of devices may be deployed in an attempt to enrol others to the claims being made. A number of rhetorical ploys, involving persuasive moves, are described which can be summarised within the sociology of translation (Callon, 1986). In addition Latour examines the manner in which additional weight may be attached to claims, by using spokespersons and the enrolment of non-human resources. These allies in the fact production process include inscriptions and technological devices.

Spokespersons: Using Authoritative Actors to Convince - At the hospital a number of uses of spokespersons was seen. In a seminar presentation a urologist from Christchurch demonstrated the power of a casemix system. He acted as spokesperson for the system, making use of his clinical background combined with high tech computer slides. The presentation consisted of a series of inquiries of a casemix system. Casemix reports were produced showing high degrees of aggregation but allowing clinicians or others to make selected enquiries of the data. Such enquiries were used to illustrate in stages the ability of the casemix system to produce more and more detailed information.

A budget overrun at the departmental level, after several screens of data and appropriate menu choices, was revealed to be a consequence of two or three very long stay patients. Patient details were available, on screen, and additional data on clinical procedures and other aspects of the treatment episodes were displayed. The whole presentation was convincing. The speaker handled several technical questions with great confidence. The audience, mainly clinicians and nurses, appeared very impressed. Only later did the speaker reveal that the example was entirely contrived, that the existing casemix system at Christchurch could not provide the information in the format or detail, which had been presented. A very convincing demonstration had been presented but only after the efforts of other people to gather the data, produce the analysis and create mock-ups of the required computer screens. The seminar was a resounding success, the medical staff present were generally impressed with the flexibility of the casemix system. 
In other situations people from the company, called Transition, who supplied the software and data processing facilities to the hospital acted as spokespersons. The Transition organisation maintains an active support organisation which sends people to visit users on a regular basis. In the case of New Zealand users, this typically has involved experts "spokespersons" from the US or in other instances Australia. Other spokespersons are recruited from other user organisations.

Spokespersons provide convincing illustrations of the value of casemix budgeting and the use of nonfinancial measures in the development of clinical protocols. As a matter of course these promoters of casemix and Transition implicitly and explicitly provide support for the technology as it is, and users are encouraged to develop their implementations along similar lines.

A key element in the implementation of the casemix system at the hospital involved devolving the clinical budgeting system to the divisions. These people having established a good deal of rapport as part of a centralised group will be based physically within the divisions. This will enable an implementation process which will take account of each division's needs and establish "close links between the TCB team ('Towards Clinical Budgeting') and divisional accounting people" (Implementation Plan, 1994, p.5). The breakup of the centrally located team effectively sent out spokespersons for casemix into the operating areas of the hospital.

The casemix staff who moved out to take up the positions of casemix analysts and clinical budget managers were expected to spend the greater part of their time in encouraging other groups within the divisions to use the technology. The positions they were appointed to were described by the Casemix Manager as being central to the success of the present stage of the project. These people "would be expected to establish what the information requirements of clinicians and nurse managers were within their respective divisions" (Interview, August 8th, 1994). The Implementation Plan envisaged “close links between the TCB team and divisional accounting people” and that the changes were to play a key role in bringing about “...a significant change to the atmosphere of the organisation [and] a greater degree of enthusiasm and a strong sense of partnership between clinicians and other management.” (Implementation Plan, 1994, p.2) 
Effectively they were engaged in problematising issues and enrolling others into the casemix technology. Seeking to establish casemix as a solution to existing problems in some instances, while also endeavouring to promote casemix data for other, perhaps new purposes. An example of this latter instance would be the development of unit and departmental budget reports from the casemix system. These reports which could take a flexible budget format, were regarded by the Casemix Manager as the solution to the newly problematised area of cost, cost efficiency and profitability.

It was in these aspects of the casemix system that we begin to see the part played by the information systems technology and financial and non-financial inscriptions. The next section will provide illustrations of the way accounting inscriptions were used.

Inscriptions: The Use of Data from Accounting and Information System - I was surprised during interviews at the hospital at the recurrent theme of people insisting they explain things to me by the use of diagrams. The systems division director, used a diagrammatic picture to show the options on medical coding in a coding committee meeting. A senior medical specialist showed me how his interest in using casemix data for research purposes had resulted in his graphing the patient outcomes from certain medical procedures.

... the [casemix] data has problems but it can still give me a broad idea of what types of treatment are being used and what variations... the comparisons I have made are a way of putting some of my older colleagues under some pressure to change [to new patterns of treatment]. (Senior Medical Officer, Medical and Elderly, $14^{\text {th }}$ October, 1994)

Another group in Medical and Elderly were making use of DRG ${ }^{\mathrm{ix}}$ summary data in assisting with the preparation of new protocols for asthma treatment.

In the past much of the effort required to evaluate treatments would mean a massive paperwork effort ... sorting through patient records and summarising data by hand. This has never been an attractive proposition and has invariably meant diverting doctors from patient care. Though I'm not happy to rely entirely on computer coding of patient data it's a good resource. (Specialist, Medical Division, $14^{\text {th }}$ October, 1994)

Other people of differing backgrounds consistently wanted to explain what they did or how "their" systems worked by using tables, diagrams, computer printouts and in some cases computer software: from simple spreadsheets to a complex medical coding package called a "grouper". A medical coder described the "grouper" software in the following way:

... we have a programme which works on PC. This allows us to input ICD9 coding ... [which is] translated into a DRG. Some of the clinicians are quite interested in this ... and have asked for their own copies [of the software]. (Interview, $14^{\text {th }}$ February, 1995) 
A diagram which was drawn, by way of an explanation for me, by four different people on early visits to the hospital is reproduced as figure 2 . This was a representation of the planned casemix system which had been developed by the Finance Director and the Casemix Manager. The same picture was drawn by other members of the casemix team who I interviewed in my initial visits to the site. This simple inscription of the system appeared to be a powerful way for the casemix staff to conceptualise the project.

\section{Figure 2: The Casemix System}

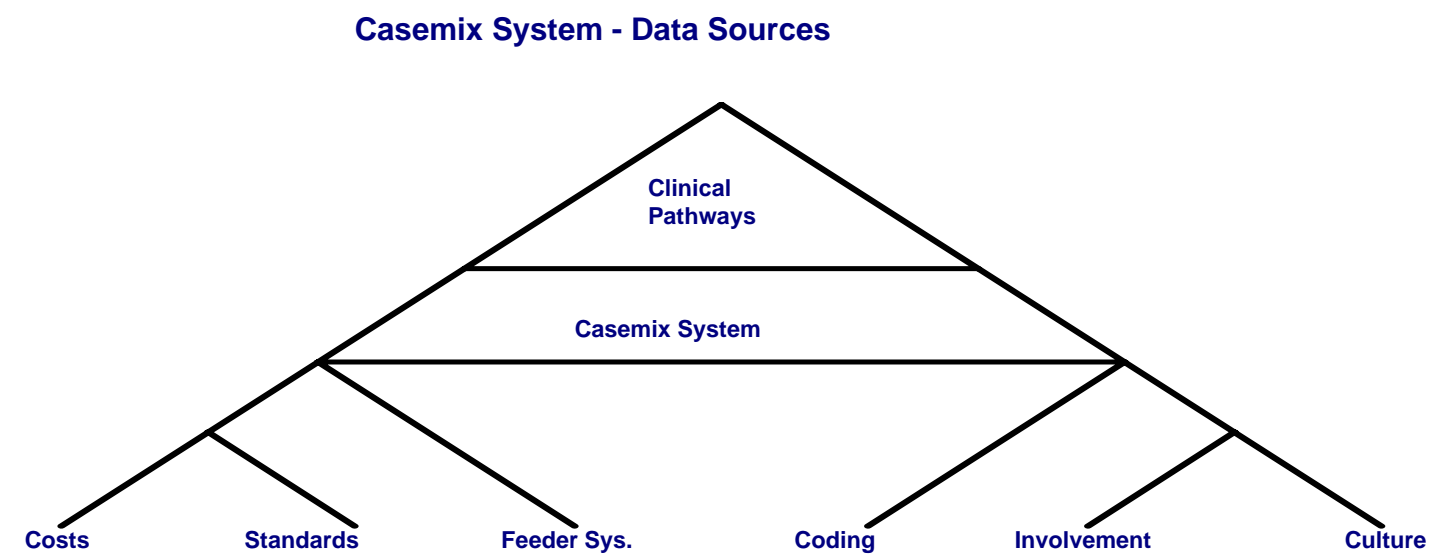

The representation of the casemix system was later to find its way into the TCB Implementation Plan (1995). It was interesting to note that the TCB Plan only came to exist a little over eighteen months after the appointment of the person who was to implement the casemix system. The Implementation Plan pulled together existing initiatives, formalised which projects were part of the project and incorporated existing conceptualisations such as the "Casemix Picture".

Graphical representations were often used to summarise data from the casemix system. I referred to a senior clinician producing graphs to summarise treatment episodes earlier. A casemix analyst also showed me computer generated pie charts which she used in discussions with clinicians on treatment regimens.

It's only when we show the docs a pie [chart] of the financials that they really get the message on how much impact length of stay makes. The impact is immediate ... they can see right away just how much "their" resources are going if patient are kept in waiting their clearance. (Interview with TCB Manager, Hospital, $18^{\text {th }}$ December, 1995) 
Another illustration of the use of a representation to persuade staff occurred in a meeting of the coding committee. This committee met on a regular basis for about 9 months from early 1994, the last meeting being held on 29th September 1994. At that meeting a surgeon raised the issue of using READ codes to provide a more appropriate level of clinical detail in the coding of clinical episodes. In response the Manager of the Systems Division explained the structure of the coding system briefly while emphasising the importance of providing information which would meet the requirements of the Ministry of Health.

We can accommodate any coding system you might want at the operational level. Since the DRG coding software can be matched to aggregate from other coding systems such as Read, in the same way that it does from ICD9. (Director, Systems Division, Meeting of the Coding Committee, $29^{\text {th }}$ September, 1994)

The Director of the Systems Division drew a picture on a white board to illustrate his answer. This is depicted as figure 3. The Director used the diagram to show in a very simple way how medical coding could proceed with either ICD9 or READ. This was in effect confirming that software could be acquired which would be capable of consolidating whatever primary coding system might be selected into the DRG codes which would provide information to organisations outside the hospital such as the Ministry of Health and Treasury. His picture was clearly intended to curtail further discussion on the issue of the choice of detailed coding system. This objective was achieved the clinicians and other medical staff were assured that a decision on coding would not be pre-empted at this stage of the project.

Figure 3: The Coding Picture

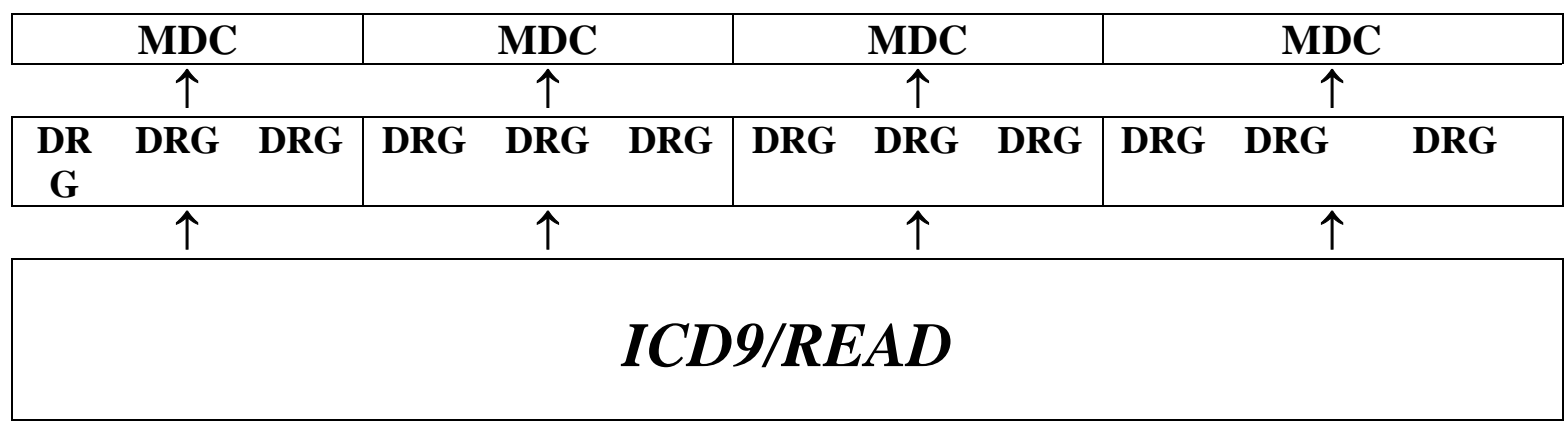

It became clear later that the clinicians within Surgery were to have less choice than the Director's remarks had appeared to suggest.

I'm thoroughly fed-up with the whole mess. I've spent hours and hours attending this group looking at the type of coding we need in theatre. I went in arguing that the medical staff needed at least the detail of Read and what happens... the whole thing is hijacked by some administrator... they don't have any idea what we need to schedule [operations in] the theatres. It's been a complete waste ... not one of the clinicians is going to take this seriously. (Senior Anaesthetist, Surgical, 2nd June, 1995) 


\section{Instruments and Technology: The Accounting and Information Systems as Actants -}

Staff at the hospital increasingly provided 'accounting' data in the course of their normal work activities. Casemix data is collected as nurses record patient acuities in order to provide evidence of their daily activities. Clinicians in completing patient medical records record diagnoses which are later coded and transformed into electronic representations.

The TCB project had become the major initiative aimed at the provision of management and contracting information. Patient treatment episodes were to be carefully coded and represented through sophisticated electronic media. The casemix system was organised around the Transition software which would provide the ability to analyse patient data and information on the use of clinical resources. Combined with the detail cost information from the hospital accounting system this was to provide a range of management control and performance reports.

...TCB is a key initiative for us. We have put a great deal of resources behind making this work. I see this a the key to providing the divisional mangers with the quality information they need. Now we have Chairman [the new general ledger system for the hospital] up to the mark, TCB will be able to draw together the financials and the management reporting we need to compete with these guys in their private practices. (Interview with Director of Finance, $24^{\text {th }}$ June, 1994)

These somewhat conventional concerns to improve management information and provide faster response in the hospitals accounting systems were to prove crucial ion increasing the presence of the Finance Director in decision making at the hospital and promoting an increasing reliance on accounting data. The TCB project was to be central in the expansion of Finance influence within the organisation.

The Transition package consists of a number of elements or report generators, which are capable of providing an array of accounting and operational performance data (figure 4). Information may be produced at various levels of aggregation.

TCB can provide great detail. It is an enormously complex information system... involving the linking of several independent software packages. TCB is a collection - a mixture of accounting and non accounting information. We are building a number of feeder systems outside of the Transition system itself. Data is collected in great detail, on individual patients and procedures... through ADT, in the wards and theatres and through Gandalf and the other information systems in clinical support services. Through TCB we can provide data in detail on individual patients, clinicians or across procedures. (Interview with TCB Manager, $1^{\text {st } J u l y, ~ 1994) ~}$

It is possible to track individual patient treatments throughout the hospital on a cost and activity basis. This would be achieved through a combination of reports from the Department Cost Manager, providing information by individual patient, and from the Product Line 
Manager, which can provide casemix analysis by individual clinician. Detailed historical reports of the patients treated, and costs of individual specialisms and indeed individual clinicians can be provided. A senior clinician regards this as an opportunity to identify best practice, provide better treatment to patients and perhaps eliminate unnecessary procedures and use resources more efficiently.

Casemix should be able to provide detail of treatment protocols used by different clinicians. When this is analysed across different patient characteristics we will be able to make significant decisions on determining best practice. Clinicians will be able to see comparisons across individual patients and each other. Managers and individual clinicians anticipate that decisions on the most effective way to treat particular conditions and especially the optimal length of hospital stay should be facilitated by this. (Interview with TCB Manager, $9^{\text {th }}$ August, 1994)

Such comparative data will clearly provide management with information with which to seek efficiencies in patient treatment. Though the casemix people tended to emphasise the value of the system to clinicians the system was clearly of considerable significance to management as the comments from interviews indicated.

Figure 4 The Transition Data Base

\begin{tabular}{|c|c|c|}
\hline \multicolumn{3}{|c|}{ Transition Database } \\
\hline $\begin{array}{l}\text { Account } \\
\text { Level } \\
\text { Budgeter }\end{array}$ & $\begin{array}{l}\text { Department Cost } \\
\text { Manager }\end{array}$ & $\begin{array}{l}\text { Product Line } \\
\text { Manager }\end{array}$ \\
\hline $\begin{array}{l}\text { * Flexible Budgeting } \\
\text { * Variance Reporting } \\
\text { * Reconciles to G/L }\end{array}$ & $\begin{array}{l}\text { * Dept. Reports } \\
\text { * Standard Costing } \\
\text { * Overhead Allocation } \\
\text { * Patient Reports }\end{array}$ & $\begin{array}{l}\text { * Operational reports } \\
\text { * Casemix Analysis } \\
\text { * Profitability Analysis } \\
\text { * Contract Monitoring }\end{array}$ \\
\hline
\end{tabular}

Transition technology is held out as having the ability to provide clinicians with a resource with which to monitor the effects of changes in treatment regimes and the impact of applying clinical pathways ${ }^{\mathrm{x}}$.

I use casemix data regularly through my PC. I can get a download of particular data and manipulate it as I want... We are looking at various areas in Medical. It takes time but we are making progress. Casemix data needs careful analysis. In theory we can pick out differences in treatment and most importantly results. There are so many variables in most medical situations... but I believe that we have 
been able to identify innovative practice and more importantly that we can spot differences and highlight these so some of the doctors who are creating outliers can see the effect of other treatment protocols. I'm not certain this will give savings in cost ...my aim is... more effective patient care (Interview with SMO Medical and Elderly, $14^{\text {th }}$ October, 1994)

Though the Department Cost Manager reporting module is only a minor element of the Transition casemix system it is illustrative of the way in which the technology enters the workings of the organisation. Elements of the technology offer at least the potential to provide allies to the overall system and the objectives of the implementation team. Department Cost Manager was being used to produce periodic management accounting reports for each unit. These reports were very different in content for different areas of the hospital. In the clinical support areas reports for units like bio-chemistry and radiology were very different to the reports produced for the surgical wards. It was interesting to note that in both cases the reports incorporated flexible budgeting techniques and used standard costing metrics to produce analysis of variances.

In a surgical ward a seven page report was produced. The first page showed aggregate budget and actual numbers and then analysis of variances. A further six pages of information provide more detail on the main elements reported on the summary page. This is a flexible budget report where volume figures are based on output measures. In the surgical wards the volume measure is primarily based on patient acuity as reflected by nursing volumes. More ill patients require more intensive nursing. 8 levels of nursing acuity are recognised, ranging from an intensive care situation where one patient may require the attention of more than one nurse to a more common requirement of perhaps $1 \frac{1 / 2}{2}$ hours per day. Other activities are also budgeted where significant: day cases; out patients and specialised dressings. Consumables are typically allowed for within the value of the nursing activity.

This facility to conduct flexible budget analysis and calculate variances is described here in order to emphasis the way in which earlier technology is continually incorporated into newer instruments. Transition makes use of a number of accounting rules and techniques in this way. In addition to standard analysis of variances established accounting rules are also available for overhead allocation. The Transition software also incorporates various mathematical devices to aid in cost allocation and reporting. One of these devices is the use of Relative Value Units throughout a number of elements of the software. 
Relative Value Units were used widely in the Clinical Services Division. Detailed costs have been worked out for services such as laboratory tests and blood products using the Relative Value Units approach. This approach makes use of the Relative Value Units mechanism within Transition in order. The Relative Value Units model allows a factor, or relative value index, to be established within the Transition System which represents the relative amount of resource consumed by one activity, test or procedure relative to another. This is similar to a traditional costing technique applied in the establishment of joint product costs. In this technique an index is established by combining a variety of quantitative features of the products produced: size; weight etc. are added to produce a numeric index value which is then used to share costs among the group of jointly produced products.

The Relative Value Units technique uses a similar approach by setting a relative value or weight for each individual procedure which can be applied subsequently to actual cost data, giving a financial value at future points in time. This process establishes a system which avoids the problem of fixed cost figures, in a standard costing system, which quickly become outdated as input costs, eg. in the case of laboratory tests, the purchases costs of chemicals change.

Our accounting and management information systems are made up of these bits of past knowledge. The techniques and technologies of accounting are composed of simple rules of addition, subtraction and data manipulation. Though none of these equations and inscription devices is complex in isolation when combined into computer software users are presented with powerful informational and representational instruments. Such technology can be surprisingly persuasive and appealing.

The above sections begin to indicate the complex interrelationships which make up organisational life. Through an admittedly limited illustration of the human and nonhuman actants which combine to constitute networks within the organisation a picture starts to emerge of the many elements which impinge on accounting system implementation in the organisation studied. Though partial the analysis intends to indicate the manner in which accounting technologies, the nature of accounting reporting and management information systems may coalesce in potentially powerful networks. These networks play a significant role in what comes to constitute organisational reality as accounting technologies provide 'evidence' of new facts about organisational events and processes. Facts become accepted as 
a consequence of the processes of modalisation as technology, human spokespersons and accounting inscriptions combine to produce increasingly convincing pictures of what is important in the organisation.

\section{Concluding Comments and Implications for Future Research}

ANT offers much to research in management accounting through its emphasis on technological systems and process. Most interpretive accounting case research has concentrated upon the social interactions which surround accounting systems, but an ANT perspective suggests a reorientation to researching the objects of accounting themselves. In ANT and the sociology of translation actants are constituted by machines and technology, as well as people. In researching accounting this means that accounting systems and techniques need to be considered as equals with the human actors in our studies of organisational interaction. The implication is that rather than looking always for a human or super human interest to explain what we find in organisations, we need to look for more mundane explanations based upon the intimacy of the bonds between people and technology. Organisational reality then is a composite of these elements, the human and the non-human, consequently what constitutes power is conditional on the ability to manoeuvre human and non-human actors in an attempt to strengthen or weaken existing associations.

Accounting systems are powerful allies of human actors (Ezzamel, 1994) but they are not entirely tame and predictable. Following Latour, our explanations ought to look less at the contrivance of human interests and more at the partly serendipitous coming together of powerfully constituted networks of somewhat poorly defined and under-determined amalgamations of human actors and accounting technology. By placing accounting systems and techniques more centrally in our research we are merely recognising in an explicit way the power we have always ascribed to accounting technologies. As a consequence the affects of accounting may often turn out to be much more mundane.

If Latour, and the argument for a symmetrical anthropology, is to be taken seriously then we need to seek to perceive accounting systems as "actant". This is a significant departure from the previous accounting literature. I see these systems, of information technology and accounting technique, as central to the constitution of our organisations. At the hospital I studied, culture, work patterns and staff interrelationships have indeed been affected by the inscription of clinical data and the reporting of cost and profit numbers by unit, division and 
clinical procedure. In the hospital as in other organisations we delegate to information systems. Additional explanatory power may be added to our research stories by recognising the constitutive role of accounting knowledge-objects.

If the applicability of a symmetrical anthropology is accepted accounting as a practice and as an object with its own existence and "agency" is placed at the centre of the research agenda. In "seeing" accounting and accounting systems as being constituted by technological "black boxes" two questions naturally follow. One concerns the processes which surround the establishment of "facts", ie. how "black boxes" are created or accepted (even if temporarily) within society. The second concerns the role of existing "black boxes" within society and organisations. What role does the accumulated knowledge which constitutes accounting play in the patterning of organisational life. Both of these are legitimate research topics.

The existing literature (Preston et al., 1992; Chua, 1995) has tended to concentrate on the first of these issues. This research has addressed the "fabrication" of accounting systems. Preston et al places much importance on "arriving before the technology becomes settled" (a phrase borrowed from Latour 1987) in order to trace the creation of a "finished" system, a closed "black box". These authors are concerned to explicate the manner in which "facts" become accepted as such. Though this is of interest to me as it was to Preston it cannot be the whole story, since as Latour clearly notes there are many more "closed" boxes than those seeking "closure". This paper has sought to concentrate on this second aspect of interpretation. The empirics presented earlier are intended to give emphasis to the conception of accounting as knowledge-object. Accounting seen in this light provides opaque black-boxed facts. Accounting information systems produce useful facts in the form of believable inscriptions. The facts, such systems provide are accepted by organisational members as useful devices to reduce uncertainty. The representations provided by such information systems are used to maintain and manage organisational boundaries (Llewellyn, 1994).

While it can be argued that the accounting systems such as casemix budgeting in hospitals may never reach "closure" the same is harder to say of DRGs and systems of medical coding. We also need to recognise that any of these "closed" boxes are potentially open to "re-opening”. There are interesting concerns around these two research aims. How to portray the role of already existing black boxes without giving the impression that they are closed for all time? They are indeed only social constructions. How to balance the explication of the 
fragile nature of a new system implementation with the, often powerful, influence of accepted accounting practice and technique?

In applying an ANT perspective clear outcomes from the research process are that much less likely. Outcomes will usually be local, not generalisable, subjective and uncertain. Such approaches are difficult to categorise. A key effect of such research is the acceptance of uncertainty, an acceptance of the partial and temporal nature of all knowledge. The characteristic of research, which takes seriously accounting as an actant, is a move to see accounting and accounting practice as central to the explication of accounting's role. Additional explanatory power may be added to our research stories by recognising the constitutive role of accounting knowledge-objects. The power of accounting systems draws from their placement within networks of accountability and the fabrication of information. If we do consider people to be the institutors of accounting systems then these people are effectively selecting accounting systems at least in part because of their nature as actants, because they are able to constrain and at other times to liberate. Accounting possesses these powers which do enable "action at a distance". Accounting does bring with it the promise, if not the power, of remote control. Whether accounting is able to deliver on its promises depends on the circumstances which surround any implementation.

There are issues of where to from here? What is at stake in an interpretation of the human actors responding to the technology? Being in some ways subordinated to it. People do indeed delegate to technology and this does result in differing patterns of relationships than might otherwise be the case. Management accounting research might begin in this style to bring together different strands in the literature. No longer must we keep the "sociological" studies away from the technological (studies of accounting systems). 


\begin{abstract}
Notes
${ }^{\mathrm{i}}$ Latour (1994) uses this term to refer to what makes(-up) societies macro actors. Latour uses the phrase "black boxes" to refer to the contribution of science and technology to contemporary society. The boxes comprise most clearly scientific instruments and technological objects. These objects mix into the fabric of society and provide "allies" which enable things to happen, organisations to grow; some individuals to accumulate power and so on.
\end{abstract}

${ }^{\text {ii }}$ ANT is associated particularly with Latour and Callon though John Law (1997) is credited with inventing the term. Latour (1999) has been rather reluctant to use the term. He has expressed strong doubts over it's value as a phrase describing the type of research it has come to refer to and the way in which the term has been employed by others '[the ANT] theory has been often misunderstood and hence much abused' (Latour, 1999, p.1). Law has also remarked on the difficulty of providing a definition of ANT 'ANT is in itself not homogeneous' (Law, 1997).

iii The best-known researchers in this tradition are Barnes $(1977,1982)$, Bloor $(1982,1991)$ and Shapin (1982; Shapin and Schaffer, 1985). These writers have looked to relate the development of scientific knowledge to changes in social interests. Interest theory represents another; attempt to develop a realist version of a particular arena of scientific work; indeed, it is even more ambitious, for not only does it depend on producing a realist account of scientific events, beliefs and groupings but it also has to co-ordinate this with a similarly definitive account of the nature of particular social groupings, classes and their ideologies

iv This approach, which is identified with Collins $(1975,1981,1983,1985)$, shows a particular concern with the "storybook" version of scientific knowledge. The storybook approach, most clearly associated with Merton, is premised upon the idea that errors in science may be explained as the result of social or psychological factors such as prejudices and personal while true knowledge is rationalised as the "getting of true knowledge" or "coming closer to nature". The problem with this work is that it assumes that what scientists take as valid scientific knowledge needs no social explanation, for it is adequately accounted for by the nature of the natural phenomena that are being studied (see Collins 1981; Collins and Cox, 1976).

Collins proposed that a form of methodological relativism is crucial for SSK. That is, scientists' claims about what is true and false should not be taken as the start point for analysis but should become a topic of analysis in their own right. (Potter, 1996, p.25 emphasis in original)

Latour (1987) also writes within this perspective particularly in the manner in which he provides sociological accounts of scientific controversies.

v Both Latour and John Law (1997) speak of "delegating" to machines and technology. This is not, necessarily or, ordinarily conscious. As a consequence it would seem improbable that we might expect to reveal the consequences of such eventualities through research methods which concentrate exclusively or primarily on the analysis of discourse, and the presentation of evidence in the form of "direct" quotes. On the contrary, following Latour it seems to me that the examination of inscriptions and documentation, and attempts to understand systems through interview and observation are much more likely to reveal the data which I feel to be central. I fully accept that this is likely to cause problems of authenticity, of convincing readers of the importance and the level of detail of the empirical material etc. These are legitimate concerns I have for my research and most particularly its presentation to an academic audience. The resulting case studies are in some danger of appearing to be "like" a conventional "functionalist" case study.

${ }^{\text {vi }}$ I do not want to appear to say that Latour or ANT see no place for data collection through the analysis of discourse gained through interview, archives or other sources. Clearly this is not the case (see Latour 1988d and 1996). But this does not mean that all knowledge can be gained in this manner. It is much clearer to me now that authors such as Chua (1995) and to a slightly lesser extent 
Bloomfield (for instance, 1995) appear to favour the more conventional (interpretive research) approach of presenting much of their data and supporting description through direct quotation of participants. Some of Latour's most simple illustrations of the impact of quasi-objects on behaviour, such as the key fob or the sleeping policeman, are clearly not amenable or tractable to research methods which privilege discourse.

vii This is a strong reflection of Collins and Yearley. It would seem to me that the concerns of writers such as Chua and Collins and Yearley are influenced to a significant extent by a critical humanist perspective, which I respect. On the other hand I feel much attraction for the arguments of Callon and Latour (1992) that their approach offers new possibilities for understanding and certainly description which are closed off in some other perspectives. The debate between Collins and Yearley (1992a and 1992b) and Callon and Latour (1992) engages directly the concerns of both sets of authors about what is gained and what may be lost in taking on another theoretical framework in SSK.

viii Some other writers are uncomfortable with the Latourian stance on symmetry in the treatment of human and nonhuman actors (Amsterdamska, 1990, Chua, 1995; Collins and Yearley, 1992a, 1992b). I am not so convinced of the folly of this conceptualisation of "human" affairs. For me it is not about accepting or proving that machines need to be able to act as humans (Collins and Yearley, 1992a) to be theorised in the manner that Latour does, it is much more to do with an acceptance of the "joint production" of society and technology. This conception needs far less critical conditions to be accepted. It is rather the ability of machines to influence than to act and behave "in themselves". Machines and technology produce both intended and unintended effects on human actors.

${ }^{\text {ix }}$ A number of medical classification systems are available including ICD-9, READ and DRG. The latter can be argued to be management-oriented, while the two former have more clinical relevance (Bloomfield, 1991). The more detailed, practitioner-developed READ codes can be mapped on to the internationally widespread ICD-9 (International Classification of Diseases Ninth Revision) codes. Both systems can be mapped on to the much simpler DRG (Diagnosis Related Groups) system.

${ }^{\mathrm{x}}$ This is the term used to describe the development of standardised treatment protocols for certain identified conditions 


\section{References}

Amsterdamska, O., (1990). Surely, You Must be Joking, Monsieur Latour! Science, Technology and Human Values 15: 495-504.

Ansari, S. and Euske K J., (1987) Rational, Rationalizing and Reifying Uses of Accounting Data in Organizations, Accounting Organizations and Society, pp. 549-570.

Berry, A. J., Capps, T., Cooper, D., Ferguson, P., Hopper, T. and Lowe, E. A., (1985) Management Control in an Area of the NCB: Rationales of Accounting Practices in a Public Enterprise, Accounting, Organizations and Society, pp. 3-28.

Bloomfield, B.P., (1991) The Role of Information Systems in the UK National Health Service: Action At a Distance and the Fetish of Calculation, Social Studies of Science, pp. 701-734.

Bloomfield, B.P., (1995) Power, Machines and Social Relations: Delegating to Information Technology in the National Health Service, Organization, pp. 489-518.

Bloomfield, B P and Best, A., (1992). "Management consultants: systems development, power and the transaltion of problems", Sociological Review, 40, 533-560.

Bloomfield, B. P., Coombs R., Cooper D.J. and Rea D., (1992) "Machines and Manouvres: Responsibility Accounting and the Construction of Hospital Information Systems." Accounting, Management and Information Technology, pp.197-219.

Bloomfield, B. P., Coombs R., Owen, J., and Taylor, P. (1997) Doctors as Managers: Constructing Systems and Users in the National Health Service in Bloomfield (ed) Information technology and Organisations; Strategies, Networks and Integration, Oxford University Press

Bloomfield B. P. and Vurdubakis T., (1997a) Paper Traces: Inscribing Organisations and Information Technology in Bloomfield (ed) Information technology and Organisations; Strategies, Networks and Integration, Oxford University Press.

Bloomfield B. P. and Verdubakis T., (1997b) Visions of Organisation and Organisations of Vision: The Representational Practices of Information Systems Development Accounting Organizations and Society, p.639-668.

Boland, R. J. Jr. and Pondy. L R, (1983) Accounting in Organizations: a Union of Natural and Rational Perspectives, Accounting Organizations and Society, pp. 223-234.

Bourdieu, P., (1977), Outline of a Theory of Practice. Cambridge: Cambridge University Press.

Burchell, S., Clubb, C. and Hopwood, A. G., (1980) The Roles of Accounting in Organizations and Society, Accounting, Organizations and Society pp. 5-27.

Burrell, G. and Morgan, G., (1979) Sociological Paradigms and Organisational Analysis, London, Heinemann.

Callon, M., (1980) Struggles and Negitiations to Define What is Problematic and What is Not the Sociologic of Translation, in Knorr, K.D., Krohn, R. and Whitley, R, (eds), The Process of Scientific Investigation Dordrecht: D. Reidel.

Callon, M., (1986),'Some elements of a sociology of translation: domestication of the scallops and the fishermen of St Brieux Bay', in Power, Action and Belief: A new sociology of Knowledge?, ed. John Law, pp.196-229, London: Routledge and Kegan Paul.

Callon M. and Latour, B., (1992) Don't Throw the Baby Out with the Bath School! A Reply to Collins and Yearley. In Pickering ed., Science as Practice and Culture. The University of Chicago Press. p.343-368.

Collins H. and Yearley, S., (1992a) Epistemological Chicken. In Pickering ea., Science as Practice and Culture. The University of Chicago Press. p.301-326. 
Collins H. and Yearley, S., (1992b) Journey into Space. In Pickering ed., Science as Practice and Culture. The University of Chicago Press. p.369-389.

Chua, W. F., (1995) Experts, Networks and Inscriptions in the Fabrication of Accounting Images: A Story of the Representation of Three Public hospitals, Accounting Organizations and Society pp.111145.

Chua, W. F., (1986) Radical Developments in Accounting Thought, The Accounting Review, 9/4, pp. 601-632.

Clegg, S. R., (1995) Book Review of We Have Never Been Modern by B Latour, Theory Culture and Society, 12/4.

Cooper, R. (1992), Formal Organization as Representation: Remote Control, Displacement and Abbreviation in Rethinking Organization (eds M. Reed and M. Hughes) pp. 254-72, Sage, London.

Cooper, R. (1995). 'Assemblage' Notes. http://www.keele.ac.uk/depts/stt/staff/rc/pubs-RC1.htm, Centre for Social Theory and Technology, Keele University.

Drucker P.F., (1993), Post-Capitalist Society. New York: HarperCollins.

Elam, M., (1999). "Living Dangerously with Bruno Latour in a Hybrid World." Theory, Culture and Society.

Ezzamel, M., (1994) Organizational Change and Accounting: Understanding the Budgeting System in its Organizational Context, Organization Studies, p. 213-240.

Ferreira, L.D. and Merchant, K. A. (1992) Field Research in Management Accounting and Control: A Review and Evaluation, Accounting, Auditing and Accountability Journal, p.3-34

Giddens, A. (1990) The Consequences of Modernity. Stanford, CA: Stanford University Press.

Giddens, A. (1994) 'Living in a Post-Traditional Society', in U. Beck, A. Giddens and S. Lash, Reflexive Modernization. Stanford, CA: Stanford University, Press.

Habermas, J., (1972) Knowledge and Human Interests London: Heinemann.

Habermas, J., ([1981] 1989), The Theory of Communicative Action, Boston, MA: Beacon Press.

Hopper, T. and Powell, A., (1985) Making Sense of Research into the Organizational and Social Aspects of Management Accounting: A Review of its Underlying Assumptions, Journal of Management Studies, 22:5, pp 429 - 465.

Hopper, T., Storey, J. and Willmott, H., (1987) Accounting for Accounting; towards the development of a dialectical view, Accounting Organisations and Society, 12, pp.537-546.

Humphrey, C. and Scapens, R.W., (1996) Methodological themes: theories and case studies of organisational accounting practices: limitation or liberation, Accounting, Auditing and Accountability Journal, pp. 87-106.

Kaplan, R. S., (1984) The Evolution of Management Accounting, The Accounting Review. pp.390418.

Kaplan, R. S., (1986) The role for empirical research in management accounting. Accounting Organisations and Society, 11, pp.429-452.

Knorr Cetina. K. (1994) A Sociological Notion of Fiction. Theory, Culture and Society, vol.11: 1-22.

Knorr Cetina, K. (1996) 'Epistemics in Society', in W. Heijman, H. Hetsen and J. Frouws (eds) Rural Reconstruction in a Market Economy. Wageningen: Mansholt Institute.

Knorr Cetina. K. (1997a) Epistemic Cultures. Cambridge. MA: Harvard University Press.

Knorr Cetina. K. (1997b) 'Objectual Practice', in K. Knorr Cetina, E.v. Savigny andT. Schatzki (eds) Thinking Practices: The Practice Approach in Social Thought. Cambridge, MA: MIT Press. 
Knorr Cetina. K. (1997c) Sociality with Objects: Social Relations in Postsocial Knowledge Societies. Theory, Culture and Society vol.14 (4): 1-30.

Latour, B., (1987), Science in Action: How to Follow Scientists and Engineers Through Society, Milton Keynes: Open University Press.

Latour, B., (1988) The Politics of Explanation, in Woolgar, S. (ed), Knowledge and Reflexivity London: Sage).

Latour, B., (1993). We Have Never Been Modern. Harvard.

Latour, B., (1994) On Technical Mediation - Philosophy, Sociology, Genealogy Common Knowledge Vol 3(2); p.29-64.

Latour, B., (1996). Aramis: or the love of technology. Brighton: Harvester Wheatsheaf.

Latour, B., (1999) On Recalling ANT, in J. Law and J. Hassard (eds) Actor Network Theory: and After, p.15-25, Oxford: Blackwell.

Latour, B. and Woolgar S., ([1979] 1986), Laboratory Life: The construction of scientific facts (2nd edn with a new postword), Princeton, NJ: Princeton University Press.

Law, J., (1986), 'On the methods of long-distance control vessels navigation and the Portuguese route to India', in Power, Action and Belief: A new sociology of knowledge?, ed. John Law, pp.23 63, London: Routledge and Kegan Paul.

Law, J., (1991) (Ed.) A Sociology of Monsters? Essays on Power, Technology and Domination, Sociological Review Monograph (pp. 26-56). London: Routledge.

Law J., (1996) Organizing accountabilities: ontology and the mode of accounting. In Munroe R. and Mouritsen J. (eds), Accountability: Power, ethos and the Technologies of Managing, International Thompson Business Press, London.

Law, J., (1997). Traduction/Trahison: Notes on ANT. Internet Document (Centre for Social Theory and Technology (CSTT), Keele University) at http://www.keele.ac.uk/depts/stt/staff/jl/pubs-JL2.htm

Llewellyn S., (1992) The role of case study methods in management accounting research: A comment, The British Accounting Review, March, pp 17-31.

Llewellyn S., (1993) Working in hermeneutic circles in management accounting research: some implications and applications Accounting Research, Vol 4, pp 231-249.

Llewellyn, S., (1994) Managing the Boundary; How Accounting is Implicated in Maintaining the Organization, Accounting Auditing and Accountability Journal, Vol 7 No 4, pp. 4-23

Lohd S.C., and Gaffikin M., (1998) Fabricating Cost Management Systems in an Integrated Business System Environment. The Fourth International Management Control Systems Conference, Universioty of Reading, England.

Lowe, A. D., (1997), Accounting in Action in the New Zealand Health Reform Process: An Analysis Informed by a Specific Case Study of a Major Health Provider, Unpublished Dphil Thesis, University of Waikato.

Luhmann, N. (1984) Soziale Systeme. Grundriss einer allgemeinen Theorie. Frankfurt: Suhrkamp.

Marx, K. (1968 [1887]) Das Kapital. Kritik der politischen Okonomie, Band 1. Hamburg: Europaishe Verlagsanstalt.

Miller, P., (1997) The Multiplying Machine, Accounting Organizations and Society pp. 355-364.

Miller, P. and O'Leary T., (1994) Accounting 'economic citizenship' and the spatial reordering of manufacture, Accounting Organizations and Society pp. 15-43.

Morgan, G., (1984) Opportunities Arising from Paradigm Diversity, Administration and Society, 16/3, pp. 306-327. 
Morgan, G., (1988) Accounting as Reality Construction: Towards a New Epistemology for Accounting, Accounting, Organizations and Society pp. 477-486.

Morgan, G. and Smircich, L., (1980) The case for qualitative research, Academy of Management Review, 5, 491-500.

Munroe, R., (1999) Power and Discretion; Membership Work in the Time of Technology, Organization, p391-404.

Potter, J., (1996). Representing Reality: Discourse, Rhetoric and Social Construction, Sage Publications.

Preston, A.M., Cooper, D.J. and Coombs, R.W. (1992) "Fabricating Budgets: A Study of the Production of Management Budgeting in the National Health Service" Accounting, Organizations and Society pp. 561-593.

Robson, K., (1991) On the Arenas of Accounting Change: The Process of Translation, Accounting, Organizations and Society pp.547-570.

Robson, K., (1992) Accounting Numbers as "Inscription"; Action at a Distance and the Development of Accounting, Accounting, Organizations and Society pp. 685-708.

Robson, K., (1994) Inflation Accounting and Action at a Distance: The Sandilands Espisode", Accounting, Organizations and Society pp. 45-82.

Scapens, R.W., (1990) Researching Management Accounting Practice: The Role of Case Study Methods British Accounting Review pp 259-281.

Scapens, R.W., (1992) The role of case study methods in management accounting research: a personal reflection and reply, British Accounting Review pp 369-383.

Slater, D. (1997) Consumer Culture and Modernity. Cambridge: Polity.

Spicer, B. H., (1992) The resurgence of cost and management accounting: a review of recent developments in practice, theories and case research methods, Management Accounting Research, 3, p.1-37.

Tomkins, C. and Groves, R., (1983) The Everyday Accountant and Researching His Reality, Accounting, Organizations and Society, Volume 8, No. 4, pp. 361-374.

Weber, M. (1905/1930) The Protestant Ethic and the Spirit of Capitalism. New York: Scribner.

Woolgar, S., (1988), Science: The very idea, London 


\section{OTHER PAPERS IN THIS SERIES}

1. Lawrence, S.L. Rational and social aspects of management accounting practice: report of a field study, June 1990.

2. Northcott, D.N. Capital budgeting in practice: past research and future directions, August 1990.

3. Cheung, J., Vos., E. and Low, C.K. IPO underpricing in New Zealand, September 1990.

4. Van Peursem, K.A. Extant research in public sector accountability, March 1991.

5. Van Peursem, K.A. New Zealand auditor perceptions: difficult and critical audit procedures, July 1991.

6. Alam, M. The budgetary process from information processing perspectives, September 1991.

7. McCracken, T. \& Hooper, K. The New Zealand goods and services tax (GST): identifying the problem areas, September 1991.

8. Lowe, A. Strategic management accounting, September 1991.

9. McCracken, T. Pricing: a review of contemporary approaches, February 1992.

10. Cheung, J. Estimating costs of capital for small ventures, March 1992.

11. Cheung, J., Vos, E., \& Bishop, D. Pre-holiday returns in the New Zealand share market, May 1992.

12. Van Peursem, K.A. Accountability for social policy: a moral framework, June 1992.

13. Alam, M. \& Poulin, B.J. Budget as a discipline: lessons from a turnaround enterprise, December 1992.

14. Raj, M. Pricing options on short and long-term yields using stochastic arbitrage based models, May 1993.

15. Godfrey, A. \& Hooper, K. Domesday Book: its significance as an accounting document, June 1993.

16. Van Peursem, K.A., Lawrence, S.R. \& Pratt, M.J. Health management performance: a classification and review of measures and indicators, July 1993.

17. Coy, D. \& Goh, G.H. Overhead cost allocations by tertiary education institutions 1989-91, September 1993.

18. Coy, D., Dixon, K. \& Tower, G. The 1992 annual reports of tertiary education institutions: quality, timeliness and distribution, November 1993.

19. Van Peursem, K.A. \& Tuson, C. Financial reporting in Area Health Boards 1987-1992, January 1994.

20. Vos, E. \& Davey, H. Time consistent accounting standards as a necessary condition for relating "point in time" accounting information to market returns, April 1994.

21. Coy, D., Buchanan, J. \& Dixon, K. The users of New Zealand tertiary education institutions' annual reports: who are they and what information do they seek? December 1994.

22. Coombes, R. \& Davey, H. The New Zealand accountant's role in environmental accountability, December 1994.

23. Wells, P.K. Marketing regulation and compliance programmes, November 1995.

24. Haslam, J. Analysis of accounting as at the end of the Napoleonic war: towards a critical theoretical history of the prescribing of accounting by the British State, November 1995. 
25. Haslam, J. The British state and the prescribing of accounting, 1815-1830: a focus upon the regulating of friendly societies and savings banks in the post-Napoleonic war context, November 1995.

26. Haslam, J. Accounting publicity and the revolution in government, November 1995.

27. Haslam, J. Accounting history as critique of the present: a critical theorising of interfaces between accounting nd the British state of the early 1840s, November 1995.

28. Dosa, L., Gallhofer, S. \& Haslam, J. Accounting's location in a transition process: a focus upon Hungary, November 1995.

29. Gallhofer, S. \& Haslam, J. Accounting on the road: turnpike administration in early nineteenth century Britain, November 1995.

30. Ciancanelli, P., Gallhofer, S., Haslam, J. \& Watson, R. Pay systems and social ideology: the case of profit related pay, November 1995.

31. Jenkin, Erica and Van Peursem, Karen A. Expert systems in auditing: New Zealand auditor perspectives, November 1995.

32. Wells, P.K. Marketing regulation and compliance programmes: attitudes and reactions of New Zealand marketing managers in 1988, November 1995.

33. Davey, H.B., Bowker, T. \& Porter, B. New Zealand's controlled foreign company regime, November 1995.

34. Davey, H.B., Barnes, H. and Porter, B. External environmental reporting: the need for a New Zealand standard, November 1995.

35. Lawrence, Stewart, Rethinking professional ethics: a religious metaphor for accountants, November 1995.

36. Ciancanelli, P., Watson, R., Gallhofer, S. \& Haslam, J. Alternative perspectives on finance: a critical analysis, November 1995.

37. Gallhofer, Sonja \& Haslam, J., Beyond accounting: the possibilities of accounting and "critical" accounting research, November 1995.

38. Gallhofer, Sonja, "It really challenged everybody": accounting and critical and feminist pedagogy, January 1996.

39. Gallhofer, Sonja, and Haslam, Jim, The direction of green accounting policy: critical reflections, January 1996.

40. Wells, P.K., Marketing regulation and compliance programmes: attitudes and reactions of New Zealand marketing managers in 1995, February 1996.

41. Pratt, Michael and Coy, David, Managing teaching allocations in a university department: the TAMM model, June 1996.

42. Coy, David and Pratt, Michael, The spider's web: politics and accountability in universities, June 1996.

43. Doolin, Bill, Organisational roles of decision support systems, June 1996.

44. Beale, Bob and Davey, Howard, The nature and origins of comprehensive income, August 1996.

45. Davey, Howard, and Holden, Mark, Emerging directions in the evaluation of foreign subsidiary performance, September 1996.

46. Kelly, Martin, A personal perspective on action-research, October 1996.

47. Doolin, Bill, Defining decision support systems, November 1996. 
48. Gallhofer, Sonja, Haslam, Jim and Pratt, Mike, Developing environmental accounting: insights from indigenous cultures, November 1996.

49. Ciancanelli, Penny, Gallhofer, Sonja, Haslam, Jim and Watson, Robert, In the name of an enabling accounting: critical reflections developed and enhanded through an analysis of accounting and profitrelated pay, November 1996.

50. Lowe, Alan, The role of accounting in the processes of health reform: providing a "black box" in the cost of blood products, November 1996.

51. Coy, David and Buchanan, John, Information technology diffusion among business professionals: Preliminary findings of a longitudinal study of spreadsheet use by accountants 1986-96, February 1997.

52 Beale, Bob and Davey, Howard, Total recognised revenues and expenses: an empirical study in New Zealand, March 1997.

53. Coy, David, Nelson, Mort, Buchanan, John and Jim Fisher, Spreadsheet use by accountants in Australia, Canada and New Zealand: preliminary findings, March 1998.

54. Wells, P.K., Manapouri: catalyst or consequence? October 1998.

55. Lowe, Alan, Tracing networks through case studies, October 1998.

56. Kim, S.N. and Mfodwo, K., Prospects for the establishment of Islamic banking in New Zealand: a contextual analysis, November 1998.

57. Van Peursem, K.A., Method for a methodology: a new approach for the middle range, November 1998.

58. Locke, Joanne and Perera, Hector, An analysis of international accounting as a catalyst for the reintegration of accounting research, August 1999.

59. Julian, Aileen and Van Peursem, Karen, Ethics education and the accounting curriculum: can ethics be taught?, August 1999.

60. Van Peursem, K.A., Wells, P.K. and L Huillier, B. Contracting services in SMEs: A New Zealand professional accounting firm case study, September 1999.

61. Lowe, Alan, Accounting in health care: providing evidence of a real impact, September 1999.

62. Alam, Manzurul and Wells, Philippa, Control systems of government-owned business enterprises: a critical analysis of the New Zealand model, November 1999.

63. Kelly, Martin, In Praise of Holistic Education in Accounting, December 1999.

64. Smith, Susan Ann and Coy, David, The quality of city council annual reports, 1996-97 and 1997-98: Preliminary findings, March 2000.

65. Hooper, Keith and Low, Mary, Representations in accounting: the metaphor effect, June 2000.

66. Dixon, Keith, The impact of management control across a hospital system, August 2000. 